\title{
Algoritma Warshall untuk Penyelesaian Masalah Vehicle Routing (Studi Kasus : Pendistribusian PT Semen Bosowa di Makassar)
}

\author{
Syafruddin Side ${ }^{1}$, Maya Sari Wahyuni ${ }^{1}$, dan Hadrianty Ramly ${ }^{1, \text { a) }}$ \\ ${ }^{1}$ Jurusan Matematika, FMIPA Universitas Negeri Makassar, 90224 \\ a)email: hadriantyr@ymail.com
}

\begin{abstract}
Abstrak. Warshall merupakan algoritma untuk menghitung jarak terpendek untuk semua pasangan titik pada sebuah lokasi yang dapat diubah menjadi sebuah graf berarah dan berbobot, yang berupa titik-titik (V) dan sisi-sisi (E) serta paling memiliki minimal satu sisi pada setiap titik. Vehicle Routing Problem (VRP) termasuk dalam kelas NP-hard problem dalam combinatorial optimization, sehingga sulit diselesaikan dengan metode eksak yang berlaku secara umum. Penelitian ini diawal dengan konsep matematis Penerapan Algoritma Warshall, yaitu pengambilan data Pendistribusian dari Perusahaan, pencarian bobot lintasan, mengubah kedalam matriks dengan ukuran $n \times n$ dalam hal ini matriks yang digunakan berukuran $11 x$ 11, menerapkan Algoritma Warshall dalam matriks yang diperoleh. Persamaan yang digunakan adalah pertama Representasi graf ke matriks berbobot berjarak $D=\left[d_{i j}\right]$ yaitu jarak dari vertex $i$ ke $j$; Kedua Dekomposisi dengan urutan $d_{i j}{ }^{(k)}$. $D^{(k)}$ menjadi matriks $n x n\left[d_{i j}{ }^{(k)}\right]$ batasi $k$ sampai $n$ sehingga $k=0,1, \ldots, n$; Ketiga Pengamatan struktur shortest path dilakukan dengan dua cara yaitu jika $k$ bukan merupakan vertex pada path (path terpendek memiliki panjang $\left.d_{i j}(k-1)\right)$ dan $k$ merupakan vertex pada path (path terpendek memiliki panjang $d_{i j}(k-1)+d_{i j}(k-1)$ ), hal tersebut memuat sebuah subpath dari $i$ $k e k$ dan sebuah subpath dari $k$ ke $j$. Keempat Iterasi yang dimulai dari 0 sampai dengan $n$. Berdasarkan hasil penelitian diperoleh bahwa dengan Metode Algoritma Warshall dapat menyelesaikan permasalahan penentuan rute terpendek dalam pendistribusian PT Semen Bosowa dengan menghitung jarak seluruh jalur lintasan yang ada dalam pendistribusian semen Bosowa di Makassar.
\end{abstract}

Kata Kunci : Algoritma Warshall, Masalah Vehicle Routing, Graf Berarah, Graf Berbobot, Jalur Terpendek.

\begin{abstract}
Warshall is an algorithm to calculate the shortest distance for every pair of points in a location that can be converted into a directed and weighted graph, in the form of vertex $(V)$ and edges $(E)$, and most have at least one side at any vertex. Vehicle Routing Problem (VRP) is included in the class of NP-hard problem in combinatorial optimization, making it difficult to solve with exact methods applicable in general. This study beginning with mathematical concepts Implementation of Algorithms Warshall, which is taking the data distribution from the Company, the search for weight trajectory, changing into a matrix with $n \times n$ squares in this case matrix used measuring $11 \times 11$, apply the algorithm Warshall in the matrix obtained, the second is the implementation of Algorithms Warshall using Microsoft Visual Basic programming language. The equation used is the first representation of the graph to a weighted matrix $D$ $=\left[d_{i j}\right]$ ie the distance from the vertex $i$ to $j$; The second order decomposition with $d_{i j}{ }^{(k)} . D^{(k)}$ be the nxn matrix $\left[d_{i j}{ }^{(k)}\right]$ so that the limit $k$ to $n$ for $k=0,1, \ldots, n$; Third observation structures shortest path done in two ways: if $k$ is not a vertex on the path (the shortest path length $\left.d_{i j}(k-1)\right)$ and $k$ is the vertex on the path (the shortest path length $d_{i j}(k-1)+d_{i j}(k-1)$ ), it contains a subpath from $i$ to $k$ and a subpath from $k$ to $j$. The fourth iteration numbered 0 through $n$. The result showed that the method Warshall algorithm can solve the problems of determining the shortest route in the distribution of PT Semen Bosowa by calculating the distance of the entire passage is in the distribution of cement Bosowa in Makassar.
\end{abstract}

Keywords: Algorithm Warshall, Vehicle Routing Problem, trending Graf, Graf Weighted, Shortest Path. 


\section{PENDAHULUAN}

Masalah yang dihadapi manusia semakin kompleks seiring dengan berkembangnya zaman. Kondisi ini menuntut adanya sebuah tindakan konkret untuk menemukan solusi optimum bagi setiap masalah yang terjadi. Salah satu pemecahanya masalah adalah jarak terpendek dengan menggunakan sebuah graph. Pencarian Rute terpendek merupakan suatu masalah yang paling banyak dibahas dan dipelajari sejak tahun 1950. Dalam pencarian rute terpendek, Perhitungan dapat dilakukan dengan beberapa macam algoritma (Fadillah, 2014)

Masalah vehicle routing termasuk dalam kelas NP-hard problem dalam combinatorial optimization, sehinggga sulit diselesaikan dengan metode eksak yang berlaku secara umum. Pada umumnya masalah vehicle routing diperoleh dengan metode heuristic, diantaranya menggunakan metode saving algoritmh sweep (Sarwadi \& Krismi, 2014)

Terdapat banyak algoritma untuk melakukan pencarian rute terpendek, seperti. Salah satu algoritma yang dipilih untuk menyelesaikan vehicle routing yang dikaji dalam tulisan tulisan ini, yaitu dengan menggunakan algoritma warshall. Algoritma warshall adalah algoritma perhitungan jalur terpendek yang dapat mencari semua jarak dari setiap simpul yang artinya dapat digunakan untuk menghitung bobot terkecil dari semua jalur yang menghubungkan sebuah pasangan titik, dan melakukan sekaligus untuk semua pasangan titik. .

Untuk menentukan jalur terpendek pada pendistribusian PT Semen Bosowa di Makassar dalam penelitian ini menggunakan algoritma warshall untuk penyelesaian masalah vehicle routing, dimana algoritma warshall merupakan salah satu algoritma pencari rute terpendek dan mampu membandingkan semua kemungkinan lintasan pada graph untuk setiap sisi dari semua simpul yang ada.

\section{METODE PENELITIAN}

Penelitian yang dilakukan merupakan jenis penelitian murni sekaligus terapan dengan menggunakan algoritma warshall yang bertujuan untuk mencari rute terpendek.

1. Adapun langkah-langkah yang ditempuh untuk mencapai tujuan penelitian adalah sebagai berikut:

2. Daftar pendistribusian PT Semen Bosowa untuk wilayah Makassar dengan mengambil 10 titik lokasi berbeda.

3. Pencarian lokasi dan bobot lintasan dengan menggunakan google maps

4. Bobot lintasan yang diperoleh dapat di ubah menjadi matriks bujur sangkar nxn.

5. Penerapan Algoritma Warshall dilakukan berdasarkan hasil yang di peroleh dari tahap analisa masalah.

Mekanisme algoritma warshall ini terdiri dari beberapa langkah yang harus dilakukan (Fadillah, 2014), yaitu:

1. Langkah awal yang harus dilakukan untuk menentukan shortest path dengan menggunakan algoritma Floyd Warshall adalah dengan merepresentasikan suatu graf sebagai suatu matriks berbobot. Format output berupa matriks $\mathrm{n} \times \mathrm{n}$ berjarak $\mathrm{D}=[\mathrm{dij}]$ dimana dij merupakan jarak dari vertex i ke $\mathrm{j}$.

2. Langkah kedua adalah melakukan dekomposisi Floyd-Warshall dengan urutan:

- $\operatorname{dij}(\mathrm{k})$ merupakan panjang dari shortest path dari i ke $\mathrm{j}$, sehingga semua vertex intermediate yang terdapat pada path (jika ada) terkumpul pada $\{1,2, \ldots ., \mathrm{k}\}$

- $\operatorname{dij}(0)$ dikumpulkan pada wij, yaitu tidak ada vertex intermediate.

- $\mathrm{D}(\mathrm{k})$ menjadi matriks $\mathrm{n} \times \mathrm{n}[\operatorname{dij}(\mathrm{k})]$

- Tentukan dij(n) sebagai jarak dari i ke j kemudian hitung $D(n)$.

- Hitung $\mathrm{D}(\mathrm{k})$ untuk $\mathrm{k}=0,1, \ldots, \mathrm{n}$. 
3. Langkah ketiga adalah menentukan struktur shortest path. Dalam hal ini, harus dilakukan dua pengamatan terlebih dahulu sebelum melangkah lebih jauh, yaitu :

- Sebuah shortest path tidak memuat vertex yang sama sebanyak dua kali

- Untuk sebuah shortest path dari i ke j dengan beberapa vertex intermediate pada path dipilih dari kumpulan $\{1,2, \ldots ., \mathrm{k}\}$, dengan kemungkinan :

- $\mathrm{k}$ bukan merupakan vertex pada path (path terpendek memiliki panjang dij(k-1)).

- $\mathrm{k}$ merupakan vertex pada path (path terpendek memiliki panjang $\operatorname{dij}(\mathrm{k}-1)+\operatorname{dij}(\mathrm{k}-1)$ ).

- Setelah melakukan pengamatan di atas, kemudian dilakukan penentuan shortest path dari $\mathrm{i}$ ke j yang memuat vertex $\mathrm{k}$.

- Shortest path tersebut memuat sebuah subpath dari i ke k dan sebuah subpath dari k ke j.

- Setiap subpath hanya dapat memuat vertex intermediate pada $\{1, \ldots, k-1\}$ dan sedapat mungkin memiliki nilai terpendek, kemudian beri nama panjangnya dik(k-1) dan $\operatorname{dkj}(\mathrm{k}-1)$ sehingga path memiliki panjang $\operatorname{dik}(\mathrm{k}-1)+\mathrm{dkj}(\mathrm{k}-1)$.

4. Langkah terakhir adalah melakukan iterasi yang dimulai dari iterasi ke 0 sampai dengan n. Perhitungan yang dilakukan dengan bantuan visual basic.

Hasil akhir dari algoritma Floyd Warshall adalah matriks untuk iterasi ke-n. Dari matriks ke-n ini, dapat dilihat shortest path untuk setiap vertex pada suatu graph.

\section{PEMBAHASAN}

\section{Algoritma warshall untuk Penyelesaian Masalah Vehicle Routing (Studi Kasus: Pendistribusian PT Semen Bosowa di Makassar}

Pada penelitian ini dibahas tentang bagaimana konsep matematis penyelesaian masalah vehicle routing menggunakan algoritma warshall, menentukan rute terpendek dalam pendistribusian algoritma warshall.

\section{Konsep matematis penerapan Algoritma Warshall}

Pada pengambilan data perusahan di PT Semen Bosowa di peroleh daftar nama-nama toko distributor semen Bosowa di Makassar beserta lokasinya ditunjukkan pada TABEL 4.1.

TABEL 4.1. Data Toko Distributor Semen bosowa di Makassar

\begin{tabular}{cccccc}
\hline No. & \multicolumn{1}{c}{ Nama } & Kota & Kecamatan & Alamat & $\begin{array}{c}\text { Lokasi lintang dan } \\
\text { bujur }\end{array}$ \\
\hline 1 & PT Semen Bosowa & $\begin{array}{c}\text { Kota } \\
\text { Maros }\end{array}$ & Bosowa & Tanete & $\begin{array}{c}-4.950351, \\
119.626372\end{array}$ \\
\hline $\mathbf{2}$ & Cahaya tenggara & $\begin{array}{c}\text { Kota } \\
\text { Makassar }\end{array}$ & Biringkanaya & Jl. Paccerakkang & $\begin{array}{c}-5.12716293334961, \\
119.522438049316\end{array}$ \\
\hline $\mathbf{3}$ & $\begin{array}{l}\text { Tb. Mini Depo } \\
\text { Bangunan }\end{array}$ & Kota & Biringkanaya & $\begin{array}{c}\text { Jln. Manuruki } \\
\text { Raya daya No } \\
\text { 230 }\end{array}$ & $\begin{array}{c}-5.1158618927002, \\
119.528678894043\end{array}$ \\
\hline \multirow{4}{*}{$\begin{array}{l}\text { Uakassar } \\
\text { Gunawa }\end{array}$} & Kota & Biringkanaya & $\begin{array}{c}\text { Jln. Laikang No. 6 } \\
\text { Komp. Ruko } \\
\text { Prumnas Sudiang } \\
\text { Makassar }\end{array}$ & $\begin{array}{c}-5.1014142036438, \\
119.530693054199\end{array}$ \\
\hline $\mathbf{5}$ & Hasmal & Kota & Mamajang & $\begin{array}{c}\text { Landak lama 27 } \\
\text { Makassar }\end{array}$ & $\begin{array}{c}-5.16254854202271, \\
119.420303344727\end{array}$ \\
\hline $\mathbf{6}$ & Asia Jaya II & $\begin{array}{c}\text { Kota } \\
\text { Makassar }\end{array}$ & Biringkanaya & $\begin{array}{c}\text { Jln. Manuruki } \\
\text { Raya Daya no 228 }\end{array}$ & $\begin{array}{c}-5.11585855484009, \\
119.528511047363\end{array}$ \\
\hline
\end{tabular}


Side, Wahyuni, \& Ramly

\begin{tabular}{|c|c|c|c|c|c|}
\hline 7 & Camba jaya 2 & $\begin{array}{c}\text { Kota } \\
\text { Makassar }\end{array}$ & Panakkukang & $\begin{array}{l}\text { Jl. Abd dg sirua } \\
\text { no. } 22\end{array}$ & $\begin{array}{c}-5.15101718902588 \\
119.452766418457\end{array}$ \\
\hline 8 & $\begin{array}{l}\text { Cahaya } \\
\text { cendrawasih }\end{array}$ & $\begin{array}{c}\text { Kota } \\
\text { Makassar }\end{array}$ & Mamajang & Cendrawasih 474 & $\begin{array}{c}-5.17691087722778 \\
119.40975189209\end{array}$ \\
\hline 9 & Mekar jaya & $\begin{array}{c}\text { Kota } \\
\text { Makassar }\end{array}$ & Makassar & $\begin{array}{c}\text { Sungai saddang } \\
\text { baru } 38\end{array}$ & $\begin{array}{c}-5.14742994308472 \\
119.42733001709\end{array}$ \\
\hline 10 & Fauzan jaya & $\begin{array}{c}\text { Kota } \\
\text { Makassar }\end{array}$ & Tamalate & Jl.dg.Tata Raya & $\begin{array}{c}-5.18203783035278 \\
119.41911315918\end{array}$ \\
\hline 11 & Erajaya tb. & $\begin{array}{c}\text { Kota } \\
\text { Makassar }\end{array}$ & Tamalate & $\begin{array}{l}\text { Jl.dg.tata raya } \\
\text { no. } 24\end{array}$ & $\begin{array}{c}-5.18268060684204, \\
119.419868469238\end{array}$ \\
\hline
\end{tabular}

*Sumber : PT Semen Bosowa

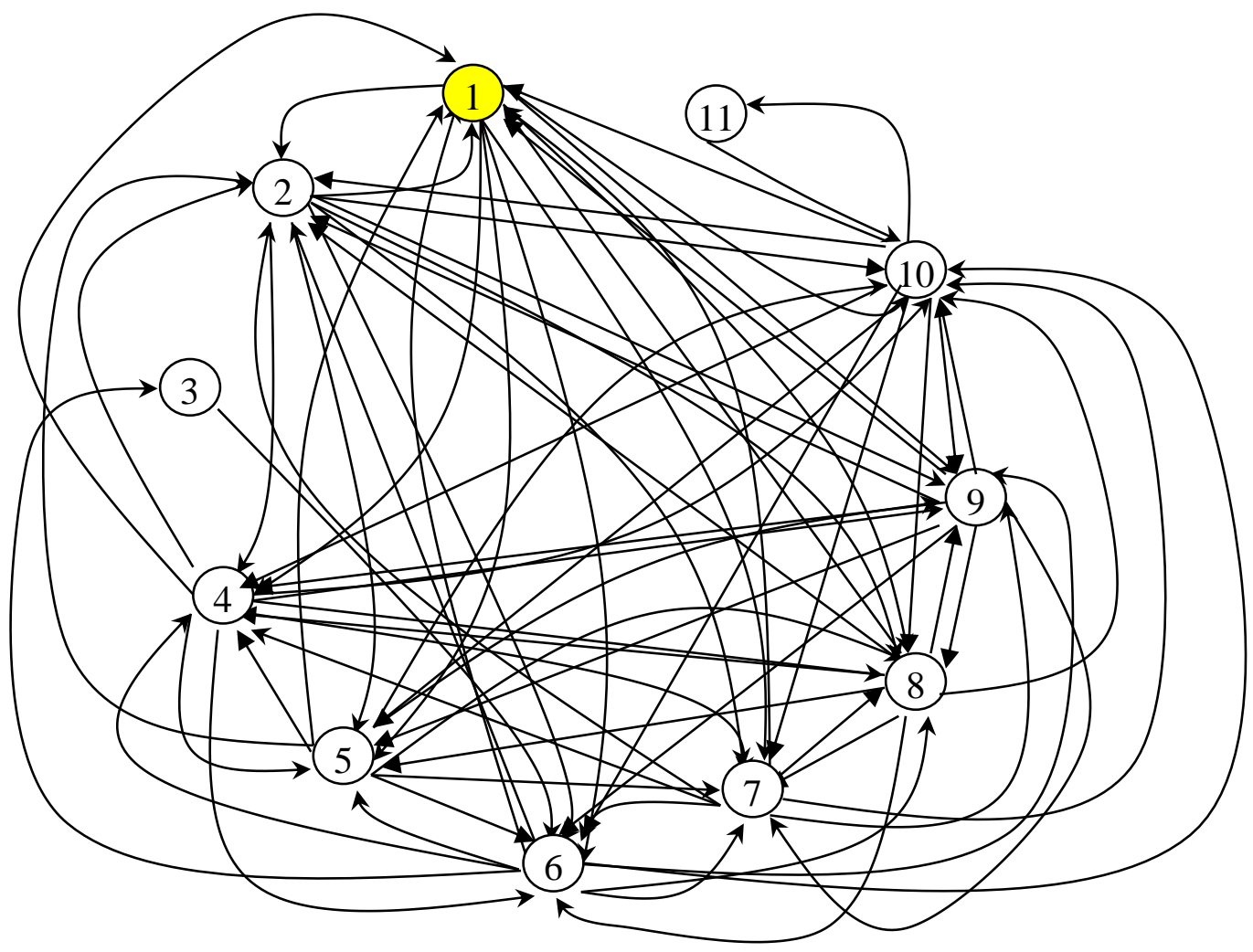

GAMBAR 4.2. Graf Berarah Lokasi Distributor Semen Bosowa di Makassar

Pemberian bobot pada graf, sesuai panjang rute yang dilalui dari sumber ke tujuan. Jika terdapat rute langsung (tanpa melalui toko lain terlebih dahulu) maka diberi bobot sesuai panjang jalurnya, jika tidak ada jalur langsung dari sumber ke tujuan, maka diberi bobot $\infty$. Hasil dari pemberian bobot pada graf disajikan pada TABEL 4.2. 
TABEL 4.2. Bobot rute jalur distribusi PT Semen Bosowa di Makassar

\begin{tabular}{|c|c|c|c|c|c|c|c|c|c|c|c|}
\hline Ke & 1 & 2 & 3 & 4 & 5 & 6 & 7 & 8 & 9 & 10 & 11 \\
\hline \multicolumn{12}{|l|}{ Dari } \\
\hline 1 & 0 & 32.9 & $\infty$ & 29.6 & 44.8 & 32.5 & 42.1 & 46.7 & 42.7 & 46.1 & $\infty$ \\
\hline 2 & 43 & 0 & $\infty$ & 4.4 & 17.1 & 2.4 & 10.4 & 19 & 15 & 18.4 & $\infty$ \\
\hline 3 & $\infty$ & $\infty$ & 0 & $\infty$ & $\infty$ & 0.018 & $\infty$ & $\infty$ & $\infty$ & $\infty$ & $\infty$ \\
\hline 4 & 39.4 & 4.4 & $\infty$ & 0 & 21.1 & 2.3 & 11.5 & 23 & 19 & 22.5 & $\infty$ \\
\hline 5 & 54.8 & 18.6 & $\infty$ & 23.6 & 0 & 17.3 & 6.6 & 2.9 & 3.2 & 2.7 & $\infty$ \\
\hline 6 & 42.4 & 2.4 & 0.018 & 2.3 & 17.5 & 0 & 10.9 & 19.4 & 15.4 & 18.8 & $\infty$ \\
\hline 7 & 52.8 & 11.5 & $\infty$ & 11.7 & $\infty$ & 11.1 & 0 & 8.1 & 4.1 & 7.5 & $\infty$ \\
\hline 8 & 57.5 & 20.4 & $\infty$ & 26 & 2.6 & 20 & 8.2 & 0 & 5.8 & 1.6 & $\infty$ \\
\hline 9 & 53.7 & 16.6 & $\infty$ & 23.1 & 2.6 & 16.5 & 5.3 & 4.9 & 0 & 4.7 & $\infty$ \\
\hline 10 & 57 & 19.9 & $\infty$ & 26.4 & 3 & 19.5 & 7.7 & 1.6 & 5.3 & 0 & 0.13 \\
\hline 11 & $\infty$ & $\infty$ & $\infty$ & $\infty$ & $\infty$ & $\infty$ & $\infty$ & $\infty$ & $\infty$ & 0.13 & 0 \\
\hline
\end{tabular}

*Sumber Gambar diolah (2016)

Data pada TABEL 4.2 dapat di ubah dalam bentuk matriks sebagai berikut:

$\left[\begin{array}{ccccccccccc}0 & 32.9 & \infty & 29.6 & 44.8 & 32.5 & 42.1 & 46.7 & 42.7 & 46.1 & \infty \\ 43 & 0 & \infty & 4.4 & 17.1 & 2.4 & 10.4 & 19 & 15 & 18.4 & \infty \\ \infty & \infty & 0 & \infty & \infty & 0.018 & \infty & \infty & \infty & \infty & \infty \\ 39,4 & 4.4 & \infty & 0 & 21.1 & 2.3 & 11.5 & 23 & 19 & 22.5 & \infty \\ 54.8 & 18.6 & \infty & 23.6 & 0 & 17.3 & 6.6 & 2.9 & 3.2 & 2.7 & \infty \\ 42.4 & 2.4 & 0.018 & 2.3 & 17.5 & 0 & 10.9 & 19.4 & 15.4 & 18.8 & \infty \\ 52.8 & 11.5 & \infty & 11.7 & \infty & 11.1 & 0 & 8.1 & 4.1 & 7.5 & \infty \\ 57.5 & 20.4 & \infty & 26 & 2.6 & 20 & 8.2 & 0 & 5.8 & 1.6 & \infty \\ 53.7 & 16.6 & \infty & 23.1 & 2.6 & 16.5 & 5.3 & 4.9 & 0 & 4.7 & \infty \\ 57 & 19.9 & \infty & 26.4 & 3 & 19.5 & 7.7 & 1.6 & 5.3 & 0 & 0.13 \\ \infty & \infty & \infty & \infty & \infty & \infty & \infty & \infty & \infty & 0.13 & 0\end{array}\right]$

Selanjutnya dibuat suatu pemisalan untuk memudahkan proses perhitungan. Misalnya dibuat pemisalan sebagai berikut :

$M$ : matriks;

$i$ : baris;

$j$ : kolom;

$n:$ jumlah titik/vertex

$k$ : perulangan ke- $n$. 
Setelah melakukan proses pemisalan variabel yang dibutuhkan, dilanjutkan dengan melakukan perhitungan short path dengan menggunakan persamaan :

$$
\begin{gathered}
M[i][j]=\min (M[i][j], M[i][k]+M[k][j] \\
\text { dengan } \mathrm{i}=1, \ldots 11, \mathrm{j}=1, \ldots 11, \mathrm{k}=1, \ldots 11
\end{gathered}
$$

Jumlah titik/vertex pada graf adalah $11(n=11)$ sehingga nilai $k=11$.

Untuk $k=1$

Untuk $i=1, j=\{1 \ldots 11\}$

$$
\begin{gathered}
M_{1,1}=\min (d(1,1),(d(1,1)+d(1,1)))=\min (0,(0+0))=0 \\
M_{1,2}=\min (d(1,2),(d(1,1)+d(1,2)))=\min (32.9,(0+32.9))=32.9 \\
M_{1,3}=\min (d(1,3),(d(1,1)+d(1,3)))=\min (\infty,(0+\infty))=\infty \\
M_{1,4}=\min (d(1,4),(d(1,1)+d(1,4)))=\min (29.6,(0+29.6))=29.6 \\
M_{1,5}=\min (d(1,5),(d(1,1)+d(1,5)))=\min (44.8,(0+44.8))=44.8 \\
M_{1,6}=\min (d(1,6),(d(1,1)+d(1,6)))=\min (32.5,(0+32.5))=32.5 \\
M_{1,7}=\min (d(1,7),(d(1,1)+d(1,7)))=\min (42.1,(0+42.1))=42.1 \\
M_{1,8}=\min (d(1,8),(d(1,1)+d(1,8)))=\min (46.7,(0+46.7))=46.7 \\
M_{1,9}=\min (d(1,9),(d(1,1)+d(1,9)))=\min (42.7,(0+42.7))=42.7 \\
M_{1,10}=\min (d(1,10),(d(1,1)+d(1,10)))=\min (46.1,(0+46.1))=46.1 \\
M_{1,11}=\min (d(1,11),(d(1,1)+d(1,11)))=\min (\infty,(0+\infty))=\infty
\end{gathered}
$$

Di atas merupakan bentuk iterasi dari sentral ke 10 toko pendistribusian PT Semen Bosowa di Makassar. Kemudian dengan cara yang sama $W[i, j]$ di hitung untuk setiap $i$ dan $j$. Perhitungan iterasi dilakukan hingga iterasi $k=11$. Dengan menggunakan algoritma warshall maka bobot yang di peroleh sebagai berikut :

$\left[\begin{array}{ccccccccccc}0 & 32.9 & 31.91 & 29.6 & 44.8 & 31.9 & 41.1 & 46.7 & 42.7 & 46.1 & 46.23 \\ 43 & 0 & 2.418 & 4.4 & 17.1 & 2.4 & 10.4 & 18.5 & 14.5 & 17.9 & 18.03 \\ 41.71 & 2.418 & 0 & 2.318 & 17.51 & 0.018 & 10.91 & 19.01 & 15.01 & 18.41 & 18.54 \\ 39.4 & 4.4 & 2.318 & 0 & 18.2 & 2.3 & 11.5 & 19.6 & 15.6 & 19 & 19.13 \\ 54.8 & 17.1 & 16.71 & 17.3 & 0 & 16.7 & 5.6 & 2.9 & 3.2 & 2.7 & 2.83 \\ 41.7 & 2.4 & 0.018 & 2.3 & 17.5 & 0 & 10.9 & 19 & 15 & 18.4 & 18.53 \\ 51.1 & 11.5 & 11.11 & 11.7 & 6.7 & 11.1 & 0 & 8.1 & 4.1 & 7.5 & 7.63 \\ 57.4 & 19.7 & 19.31 & 19.9 & 2.6 & 19.3 & 8.2 & 0 & 5.8 & 1.6 & 1.73 \\ 53.7 & 16.6 & 16.41 & 17 & 2.6 & 16.4 & 5.3 & 4.9 & 0 & 4.7 & 4.83 \\ 57 & 19.2 & 18.81 & 19.4 & 3 & 18.8 & 7.7 & 1.6 & 5.3 & 0 & 0.13 \\ 57.13 & 19.33 & 18.94 & 19.53 & 3.13 & 18.93 & 7.83 & 1.73 & 5.43 & 0.13 & 0\end{array}\right]$


Tabel dibawah merupaka tabel perbandingan bobot awal pendistribusian PT Semen Bosowa dengan metode Algoritma Warshall

TABEL 4.3. Perbedaan bobot awal dengan bobot akhir

\begin{tabular}{|c|c|c|c|c|c|}
\hline Lokasi & Bobot Awal & $\begin{array}{l}\text { Bobot } \\
\text { Akhir }\end{array}$ & Lokasi & Bobot Awal & $\begin{array}{l}\text { Bobot } \\
\text { Akhir }\end{array}$ \\
\hline$(1,1)$ & 0 & 0 & $(2,1)$ & 43 & 43 \\
\hline$(1,2)$ & 32.9 & 32.9 & $(2,2)$ & 0 & 0 \\
\hline$(1,3)$ & 1000000 & 31.91 & $(2,3)$ & 1000000 & 2.418 \\
\hline$(1,4)$ & 29.6 & 29.6 & $(2,4)$ & 4.4 & 4.4 \\
\hline$(1,5)$ & 44.8 & 44.8 & $(2,5)$ & 17.1 & 17.1 \\
\hline$(1,6)$ & 32.5 & 31.9 & $(2,6)$ & 2.4 & 2.4 \\
\hline$(1,7)$ & 42.1 & 41.1 & $(2,7)$ & 10.4 & 10.4 \\
\hline$(1,8)$ & 46.7 & 46.7 & $(2,8)$ & 19. & 18.5 \\
\hline$(1,9)$ & 42.7 & 42.7 & $(2,9)$ & 15 & 14.5 \\
\hline$(1,10)$ & 46.1 & 46.1 & $(2,10)$ & 18.4 & 17.9 \\
\hline$(\mathbf{1 , 1 1})$ & 1000000 & 46.23 & $(2,11)$ & 1000000 & 18.03 \\
\hline$(3,1)$ & 1000000 & 41.71 & $(4,1)$ & 39.4 & 39.4 \\
\hline$(3,2)$ & 1000000 & 2.418 & $(4,2)$ & 4.4 & 4.4 \\
\hline$(3,3)$ & 0 & 0 & $(4,3)$ & 1000000 & 2.318 \\
\hline$(3,4)$ & 1000000 & 2.318 & $(4,4)$ & 0 & 0 \\
\hline$(3,5)$ & 1000000 & 17.51 & $(4,5)$ & 21.1 & 18.2 \\
\hline$(3,6)$ & 0.018 & 0.018 & $(4,6)$ & 2.3 & 2.3 \\
\hline$(3,7)$ & 1000000 & 10.91 & $(4,7)$ & 11.5 & 11.5 \\
\hline$(3,8)$ & 1000000 & 19.01 & $(4,8)$ & 23 & 19.6 \\
\hline$(3,9)$ & 1000000 & 15.01 & $(4,9)$ & 19 & 15.6 \\
\hline$(\mathbf{3 , 1 0})$ & 1000000 & 18.41 & $(4,10)$ & 22.5 & 19 \\
\hline$(3,11)$ & 1000000 & 18.54 & $(4,11)$ & 1000000 & 19.13 \\
\hline$(5,1)$ & 54.8 & 54.8 & $(6,1)$ & 42.4 & 41.7 \\
\hline$(5,2)$ & 18.6 & 17.1 & $(6,2)$ & 2.4 & 2.4 \\
\hline$(5,3)$ & 1000000 & 16.71 & $(6,3)$ & 0.018 & 0.018 \\
\hline$(5,4)$ & 23.6 & 17.3 & $(6,4)$ & 2.3 & 2.3 \\
\hline$(5,5)$ & 0 & 0 & $(6,5)$ & 17.5 & 17.5 \\
\hline$(5,6)$ & 17.3 & 16.7 & $(6,6)$ & 0 & 0 \\
\hline$(5,7)$ & 5.6 & 5.6 & $(6,7)$ & 10.9 & 10.9 \\
\hline$(5,8)$ & 2.9 & 2.9 & $(6,8)$ & 19.4 & 19 \\
\hline$(5,9)$ & 3.2 & 3.2 & $(6,9)$ & 15.4 & 15 \\
\hline$(5,10)$ & 2.7 & 2.7 & $(6,10)$ & 18.8 & 18.4 \\
\hline$(5,11)$ & 1000000 & 2.83 & $(6,11)$ & 1000000 & 18.53 \\
\hline$(7,1)$ & 52.8 & 51.1 & $(8,1)$ & 57.5 & 57.4 \\
\hline$(7,2)$ & 11.5 & 11.5 & $(8,2)$ & 20.4 & 19.7 \\
\hline$(7,3)$ & 1000000 & 11.11 & $(8,3)$ & 1000000 & 19.31 \\
\hline$(7,4)$ & 11.7 & 11.7 & $(8,4)$ & 26 & 19.9 \\
\hline$(7,5)$ & 1000000 & 6.7 & $(8,5)$ & 2.6 & 2.6 \\
\hline$(7,6)$ & 11.1 & 11.1 & $(8,6)$ & 20 & 19.3 \\
\hline$(7,7)$ & 0 & 0 & $(8,7)$ & 8.2 & 8.2 \\
\hline$(7,8)$ & 8.1 & 8.1 & $(8,8)$ & 0 & 0 \\
\hline$(7,9)$ & 4.1 & 4.1 & $(8,9)$ & 5.8 & 5.8 \\
\hline$(7,10)$ & 7.5 & 7.5 & $(8,10)$ & 1.6 & 1.6 \\
\hline$(7,11)$ & 1000000 & 7.63 & $(8,11)$ & 1000000 & 1.73 \\
\hline$(9,1)$ & 53.7 & 53.7 & $(10,1)$ & 57 & 57 \\
\hline$(9,2)$ & 16.6 & 16.6 & $(10,2)$ & 19.9 & 19.2 \\
\hline$(9,3)$ & 10000000 & 16.41 & $(10,3)$ & 1000000 & 18.81 \\
\hline$(9,4)$ & 23.1 & 17 & $(10,4)$ & 26.4 & 19.4 \\
\hline
\end{tabular}


Side, Wahyuni, \& Ramly

\begin{tabular}{|c|c|c|c|c|c|}
\hline$(9,5)$ & 2.6 & 2.6 & $(10,5)$ & 3 & 3 \\
\hline$(9,6)$ & 16.5 & 16.4 & $(10,6)$ & 19.5 & 18.8 \\
\hline$(9,7)$ & 5.3 & 5.3 & $(10,7)$ & 7.7 & 7.7 \\
\hline$(9,8)$ & 4.9 & 4.9 & $(10,8)$ & 1.6 & 1.6 \\
\hline$(9,9)$ & 0 & 0 & $(10,9)$ & 5.3 & 5.3 \\
\hline$(9,10)$ & 4.7 & 4.7 & $(10,10)$ & 0 & 0 \\
\hline$(9,11)$ & 1000000 & 4.83 & $(10,11)$ & 0.13 & 0.13 \\
\hline$(11,1)$ & 1000000 & 57.13 & & & \\
\hline$(11,2)$ & 1000000 & 19.33 & & & \\
\hline$(11,3)$ & 1000000 & 18.94 & & & \\
\hline$(11,4)$ & 1000000 & 19.53 & & & \\
\hline$(11,5)$ & 1000000 & 3.13 & & & \\
\hline$(11,6)$ & 1000000 & 18.93 & & & \\
\hline$(11,7)$ & 1000000 & 7.83 & & & \\
\hline$(11,8)$ & 1000000 & 1.73 & & & \\
\hline$(11,9)$ & 1000000 & 5.43 & & & \\
\hline$(11,10)$ & 0.13 & 0.13 & & & \\
\hline$(11,11)$ & 0 & 0 & & & \\
\hline
\end{tabular}

Berdasarkan tabel di atas, dapat ditentukan rute terpendek pendistribusian PT Semen Bosowa ke seluruh toko distributor di Makassar, berturut-turut yaitu dari PT Semen Bosowa (Maros), ke UD. Shurya Gunawa (Sudiang), kemudian Tb Asia Jaya II (Daya), kemudian Tb. Mini Depo Bangunan (Daya), kemudian Tb Cahaya Tenggara (Jl. Paccerakkang), kemudian Tb Camba Jaya 2 (Jl. Abd. Dg. Sirua), kemudian Tb Mekar Jaya (Jl. Sungai Saddang Baru), kemudian Tb Hasmal (Jl. Landak Lama), Kemudian Tb Fauzan Jaya (Jl. Dg. Tata Raya), kemudian Tb Erajaya (Jl. Dg. Tata Raya), dan terakhir ke Tb Cahaya Cenderawasih (Jl. Cenderawasih), sehingga rute terpendek dari sentral ke 10 toko adalah $55.996 \mathrm{~km}$ ditunjukkan pada TABEL 4.4 .

TABEL 4.4 . Rute terpendek dari sentral ke 10 toko pendistribusian PT Semen Bosowa di Makassar

\begin{tabular}{|c|c|c|c|}
\hline No & Rute & $\begin{array}{c}\text { Jarak } \\
(\mathbf{k m})\end{array}$ & $\begin{array}{l}\text { Rute } \\
(\mathbf{k m})\end{array}$ \\
\hline 1 & PT Bosowa ke UD Shurya Gunawa $(1,4)$ & 29.6 & 29.6 \\
\hline 2 & UD Shurya Gunawa ke Asia Jaya II $(4,6)$ & 2.3 & 31.9 \\
\hline 3 & Asia Jaya II ke Tb Mini Depo Bangunan $(6,3)$ & 0.018 & 31.918 \\
\hline 4 & Tb Mini Depo Bangunan ke Tb Cahaya tenggara $(3,2)$ & 2.418 & 34.336 \\
\hline 5 & Tb Cahaya tenggara ke Tb Camba Jaya $2(2,7)$ & 10.4 & 44.736 \\
\hline 6 & Tb Camba Jaya ke Tb Mekar jaya $(7,9)$ & 4.1 & 48.836 \\
\hline 7 & Tb Mekar jaya ke Tb Hasmal $(9,5)$ & 2.6 & 51.436 \\
\hline 8 & Tb Hasmal ke Tb Fauzan jaya $(5,10)$ & 2.7 & 54.136 \\
\hline 9 & Tb Fauzan Jaya Ke Tb Erajaya $(10,11)$ & 0.13 & 54.266 \\
\hline 10 & Tb Erajaya ke Cahaya Cendrawasih $(11,8)$ & 1.73 & 55.996 \\
\hline
\end{tabular}




\section{KESIMPULAN DAN SARAN}

\section{Simpulan}

5. Hasil pencarian solusi optimum berdasarkan jarak minimum yang ditempuh pada permasalahan vehicle routing pendistribusian PT Semen Bosowa di Makassar menggunakan Algoritma Warshall $M_{1,4}=\min \left(\left(M_{1,4}\right),\left(M_{1,1}+M_{1,4}\right)\right)$

6. $\quad M_{1,4}=\min d(1,4),(d(1,1)+(1,4))=\min ((29.6),(0+29.6))=29.6$

7. Algoritma Warshall dapat menyelesaikan permasalahan penentuan rute terpendek dalam pendistribusian PT Semen Bosowa dengan menghitung jarak seluruh jalur lintasan yang ada dalam pendistribusian semen Bosowa di Makassar, dapat ditentukan rute terpendek pendistribusian PT. Semen Tonasa ke seluruh toko distributor di Makassar, berturut-turut yaitu dari PT. Semen Bosowa (Maros), UD. Shurya Gunawa (Sudiang), Asia Jaya II (Daya), Tb. Mini Depo Bangunan (Daya), Cahaya Tenggara (Jl. Paccerakkang), Camba Jaya 2 (Jl. Abd. Dg. Sirua), Mekar Jaya (Jl. Sungai Saddang Baru), Hasmal (Jl. Landak Lama), Fauzan Jaya (Jl. Dg. Tata Raya), Erajaya tb. (Jl. Dg. Tata Raya), dan Cahaya Cenderawasih (Jl. Cenderawasih)

\section{Saran}

Hasil perhitungan ini dapat digunakan sebagai dasar dalam pendistribusian Semen Bosowa di Makassar. Namun penelitian ini dapat dikembangkan untuk mendapatkan hasil yang lebih baik. Di antaranya, dengan menambahkan kapasitas penyimpanan semen di tiap titik distribusi, menambahkan variabel rute sibuk, menggunakan simpul yang lebih besar, dan menggunakan bahasa pemrograman yang berbeda.

\section{DAFTAR PUSTAKA}

Budiarsyah, D. K. (2010). Algoritma Djikstra, Bellman-Ford, dan Floyd- Warshall untuk Mencari Rute Terpendek dari Suatu Graf. Makassar: Universitas Negeri Makassar.

Fadillah, N. (2014). Algoritma Genetika dalam Penyelesaian Travelling Salesman Problem. (Skripsi, tidak dipublikasikan). Universitas Negeri Makassar, Makassar.

Sarwadi, \& Krismi, A. (2014). Algoritma Genetika untuk Penyelesaiaan Masalah Vehicle Routing. Jurnal Matematika dan Komputer. 7(2). 